\title{
A DISCRIMINANT MODEL FOR SKILL ORIENTED PREDICTION OF FEMALE CRICKETERS DEPENDING UPON SELECTED PERFORMANCE PARAMETERS
}

\author{
Sapna Mandoli ${ }^{1 \mathrm{ABCD}}$, Deepak Sharma ${ }^{1 \mathrm{ABD}}$, Hem Chandra Joshi ${ }^{1 \mathrm{ABCD}}$ \\ ${ }^{1}$ Lakshmibai National Institute of Physical Education \\ Authors' Contribution: A - Study design; B - Data collection; C - Statistical analysis; D - Manuscript Preparation; E - Funds Collection
}

Corresponding Author: Sapna Mandoli, E-mail: mandolisapna824@gmail.com

Accepted for Publication: October 16, 2021

Published: December 25, 2021

DOI: 10.17309/tmfv.2021.4.01

\begin{abstract}
Research Purpose. The study aimed to develop a discriminant model for cricketers on the basis of physiological \& anthropometric variables.

Materials and Methods. The study included sixty female seniors BCCI board players representing five different states with mean age $23.4 \pm 2.03$, mean height $152.1 \pm 3.44$, and mean weight $52.4 \pm 4.21$. A multivariate technique was used to predict the cricket performance by classifying the players into batsmen and pace bowlers on the basis of selected physiological \& anthropometrical variables.

Results. All the assumptions were positively full-filled (Shapiro-Wilk test $\mathrm{p}>0.05$ and $\mathrm{F}=8.121, \mathrm{p}=0.264$ for Box's $\mathrm{M}$ test) for applying discriminant analysis to develop the model. A total of eleven performance variables were initially selected for the study and after applying the stepwise statistical technique of discriminant analysis, the model selected certain variables namely Muscle Mass (1.311), Fat (-0.182) \& Shoulder Diameter (0.292) and showed its effectiveness as the Eigenvalue for the fit model was 0.848 .

Conclusion. A discriminant function F1 $=-29.531+(1.311 \times$ Muscle Mass $)+(-0.182 \times$ Fat $)+(0.292 \times$ Shoulder Diameter) was developed. The percentage of total variation explained by the model was $71.9 \%$. A total of $93.2 \%$ of the observations were correctly classified using the proposed discriminant model.
\end{abstract}

Keywords: discriminant model, Wilks' lambda, eigenvalue, classification matrix.

\section{Introduction}

Cricket is one of the most widely played sports in the world, every day there are 55000 cricket matches played in India alone (Ahamad et al., 2016). Since India is such a highly populated country, it is difficult to identified talent at an early stage due to a shortage of trained coaches. The word "talent" refers to a person's natural endowment of a superior quality that can be improved (Peltola, 1992; Williams \& Reaily, 2000; Mallillin et al., 2007). In today's India, most of the child wants to play cricket, and their first choice is to be a batsman rather than a bowler. However, this may not be possible because the child may have more ability to be a bowler rather than a batsman.

Different researchers identified the most important characteristics of individuals' physical, cognitive, physiological, and anthropometric abilities to identify cricketing talent (Ahmad et al., 2016). Noakes and Durandt (2000) and Hoque (2019) reported that the cricket requires physical

(c) Mandoli, S., Sharma, D., \& Joshi, H. C., 2021. potential along with the mental strength to concentrate intensely for the longer duration continuously. Whereas, Johnstone et al. (2014) reported height as a key anthropometric characteristics for bowling like bounce, length in cricket. Pyne et al. (2006) also positively correlated various anthropometric characteristics with the fast bowling performance in cricket as he reported that body shape specially arm length was dominating characteristics of fast bowling in terms of Vpeak. Christie (2012) also concluded the significant role of physical and physiological demands in cricket performance but in contrasts, Rudkin and O'Donoghue (2008) and Gore et al. (1993) concluded undemanding physical and physiological competencies for cricket performance in their study. More attention has been paid in recent years to recognizing the various anthropometric, physical and physiological variables that can differentiate an athlete's position/role in different sports (Leone et al., 2002; Koley, 2006; Landers et al., 2000). A research by Nazeer et al. (2018) also admitted the strong positive significance of anthropometric and physical fitness characteristics for optimal performance in sports competition. 
In every game and sports different factors responsible for good performance. Since the essence of the game is so peculiar, it's difficult to reliably evaluate a player. As a result, there are few scientific training programs available for cricketers (Bartlett, 2003). Cricketers' training plans were never as rigorous as the training programs for other team sports in the past (Woolmer, 2008). However, the situation has changed now that cricket has undergone significant changes with the advent of new formats such as T-20.

In most team sports, not only fitness but also physique and physiological parameters of a player are equally important, and the role or position of the players is often decided accordingly. Like in cricket pace bowlers are taller than batsmen with good shoulder width as well (Stretch, 1987). Batsmen and pace bowlers each have a distinct role to play in cricket. A batsman must possess certain characteristics that distinguish him from pace bowlers, and a pace bowler must possess certain characteristics that distinguish him from batsmen. Thus, in order to identify cricketers according to their specialties, researcher used a multivariate technique called Discriminant Function Analysis to build a model for cricketers using anthropometrical and physiological attributes as an outcome of present study. This multivariate technique combines with multiple regression and simple ANOVA which is used for classifying the set of observations into predefined groups on the basis of their predicting characteristics of which the groups can be determined (Thomas et al., 2011; Verma, 2013). Number the studied have been done using discriminant analysis for classifying the groups on the basis of playing position in football like defender and attacker (Tew \& Wood, 1980), on the basis of area of mastery like in cricket Bowler and batsmen (Bagchi \& Raizada, 2020; Pollock et al., 2013) even classifying groups on the basis of different sports like tennis, volleyball, skating, swimming (Leone et al., 2002; Pion et al., 2014).

Aim of the Study. The aim of the present study was to classify female cricketers using a variety of physiological and anthropometric variables, as well as to define the most predictive variables for both the groups.

Hypothesis. It was hypothesized that there would be the significant discriminant model developed for classifying cricketers into Batsmen and pace-bowler on the basis of some fixed predictor variables.

\section{Materials and Methods}

\section{Selection of Subjects}

For this study a total 60 senior's women board players were included with 30 batsmen and 30 bowllers with (mean age $23.4 \pm 2.03$, mean height $152.1 \pm 3.44$ and mean weight $52.4 \pm 4.21$ ). The subjects had a minimum three years or more of playing experience in the board trophy. Subjects with any kind of recent injury related to body parts (Lower and upper limb) were excluded for the study. After the explanation of the procedure a written consent form was signed by the subjects. The study was approved by the institutes Departmental Research Committee.

\section{Physiological Testing Protocols}

Proper instructions and demonstration was given to the subjects regarding the use of different physiological instru- ments. For the measurement of vital capacity portable dry spirometer was used. The subject was asked to take a deep inhalation for long as possible at least for the 6 seconds followed by a forcefully exhalation to record the vital capacity in liters. Detached mouthpieces were attached separately to the spirometer for each subject taking instrument into mouth. Two trails were given and second trail was recorded. $\mathrm{VO}_{2} \mathrm{max}$ was measured using Queen's College Phase Test. Subjects were asked to perform four-step cadence (up-updown-down) on 16 inches heighted wide box for 3 minutes continuously at the rate of 22 steps per minute. The heart beat was recorded just after 5 seconds of recovery immediately after completion of test up to 15 seconds from carotid artery and then the calculated reading of 15 seconds heart beat was multiplied by four to get the total heat beat per minute which was further used in formula [Women $\mathrm{VO}_{2} \max (\mathrm{ml} / \mathrm{kg} / \mathrm{min})$ $=65.81-(0.1847 \times$ heart rate $(\mathrm{bpm})]$ to estimate the value women's $\mathrm{VO}_{2} \max$. (McArdle et al., 1972). In addition, the researcher used Bioelectrical impedance Analyzer (BIA) also called Bio Scan to measure two body compositional (Morphologic) variables i.e. fat mass and muscles mass under correct administrative protocol. Resting heart rate was taken in the morning by radial artery using two fingers up to 10 seconds and the multiplied by 6 to get total beats per minute.

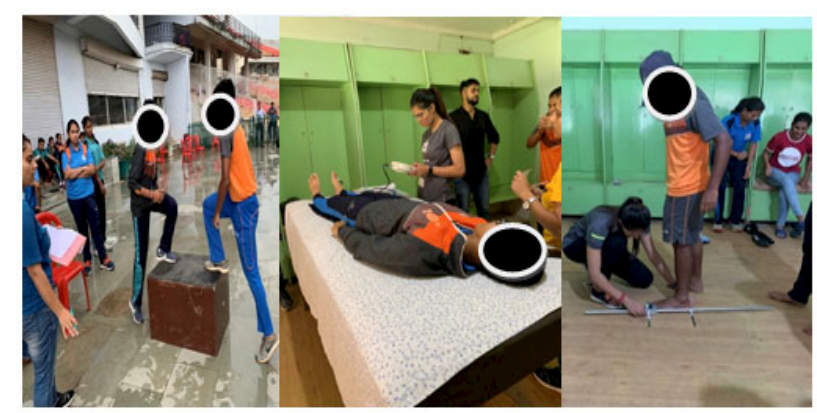

Fig. 1. Administrative Testing Protocol Illustrations

\section{Anthropometrical Testing Protocols}

Anthropometric rode was used for taking measurement of leg length, foot length, total arm length and palm length whereas; sliding caliper was used for measuring hip and shoulder diameter. The reference point for measuring hip diameter (level of greater trochanter of the two sides of hip) shoulder diameter (Distance between the most lateral points of acromial processes on either side) total arm length (distance between acromion point and dectylion point) palm length (shortest distance between Midstylion line and Dactylion) leg length (distance between the anterior superior iliac spine and the standing surface) foot length (distance between the tip of the most tarsal phalange and the most posterior part of the calcaneus) was used and data was recorded in centimeters.

\section{Statistical analysis}

The data was analyzed using IBM SPSS (version 20.0.0) software. The Shaprio-Wilk test was used to ensure that the data was normal. First, the Box M test assumption for discriminant analysis (DA) was met. The value of Wilk's lambda and the score of Eigen value were also used in the study. The model established a discriminant function with the aid of 
the most dominant factors contributed for classification purpose, which were used in the study, and the model also analyzed expected group membership (Classification Matrix).

\section{Results}

All of the assumptions were tested in order to develop the discriminant model and meet the objectives, and none of them were violated. The outcome of Shaprio-Wilk test (Table 1) was used to check the normality of the data.

Table 1. Shaprio-Wilk Test for Normality of Batsmen \&Pacers

\begin{tabular}{lcc}
\hline \multicolumn{1}{c}{ Variables } & Batsmen (Sig.) & Pacers (Sig.) \\
\hline Vital Capacity & 0.296 & 0.657 \\
$\mathrm{VO}_{2}$ max & 0.368 & 0.115 \\
Muscle Mass & 0.138 & 0.158 \\
Fat & 0.714 & 0.222 \\
Resting Heart Rate & 0.593 & 0.936 \\
Total Arm Length & 0.543 & 0.299 \\
Palm Length & 0.556 & 0.312 \\
Foot Length & 0.799 & 0.824 \\
Leg Length & 0.694 & 0.575 \\
Shoulder Diameter & 0.310 & 0.692 \\
Hip Diameter & 0.809 & 0.733 \\
\hline
\end{tabular}

Table 2. Box’s M Test For Testing Equal Population Covariance Matrices (DA)

\begin{tabular}{|c|c|c|}
\hline \multicolumn{2}{|c|}{ Box's M } & \multirow{2}{*}{$\begin{array}{r}\mathbf{8 . 1 2 1} \\
1.276\end{array}$} \\
\hline $\mathrm{F}$ & Approx & \\
\hline & df1 & 6 \\
\hline & df. & 2346.493 \\
\hline & Sig. & 0.264 \\
\hline
\end{tabular}

Table 2 indicated the result of Box M test that has reported insignificant as the $p$ value $(F=8.121, p=0.264)$ for Box $M$ test was more than 0.05 level of significance which showed no violation in the assumption of homogeneity of variances/covariance.

Table 3. Eigen Value for Developing Discriminant Model (Canonical Correlation)

\begin{tabular}{ccccc}
\hline Function & $\begin{array}{c}\text { Eigen } \\
\text { value }\end{array}$ & \% of Variance & $\begin{array}{c}\text { Cumulative } \\
\%\end{array}$ & $\begin{array}{c}\text { Canonical } \\
\text { Correlation }\end{array}$ \\
\hline 1 & 2.556 & 100.0 & 100.0 & 0.848 \\
\hline
\end{tabular}

The above table 3 indicates the values of canonical discriminant function (Eigen value) for group discriminant analysis. Here the value of canonical correlation is 0.848 . Since the total \% of variation explained by the model is expressed as the square of the Canonical correlation. Hence $71.9 \%\left(0.848^{\star}\right)$ of the independent variables in the developed model can explain variation in the two groups of cricketers.

Table 4 indicates that the value of Wilk's Lambda is significant as the $\mathrm{p}$ - value is less than .05. The value of Wilk's Lambda also indicates that $28.1 \%$ of variability is not explained by the model.
Table 4. Outcomes of Calculated Wilks' Lambda of Discriminant Function

\begin{tabular}{ccccc}
\hline Test of functions & Wilks' Lambda & Chi-square & df & Sig. \\
\hline 1 & 0.281 & 70.413 & 3 & $0.000^{*}$ \\
\hline
\end{tabular}

*significant at 0.05 level of significance

Table 5 indicates the estimation of unstandardized discriminant coefficients which are utilized in developing function of discriminant. In this investigation, the stepwise technique was applied, and only three parameters were included

Table 5. Unstandardized Canonical Discriminant Function Coefficient (DA)

\begin{tabular}{lc}
\hline \multicolumn{1}{c}{ Variables } & Function $\mathbf{1}$ \\
\hline Muscle Mass & 1.311 \\
Fat & -0.182 \\
Shoulder Diameter & 0.292 \\
(Constant) & -29.531 \\
\hline
\end{tabular}

in the model because of its critical segregating power. Different factors because of inadequate segregating power were not getting chosen in the model. Accordingly, the values of constants and unstandardized discriminant coefficients were taken to develop the discriminant function F1 \& these three selected factors as demonstrated.

EQUATION:

$\mathrm{F} 1=-29.531+(1.311 \times$ Muscle mass $)+(-0.182 \times$ Fat $)+$ $(0.292 \times$ Shoulder Diameter $)$

The above table indicates the means for the transformed group centroids. One of the basic goals of discriminant analysis is to construct a model. a decision matrix for assigning a subject into either of two groups. As a result, Group 1 (Bats-

Table 6. Functions at Group Centroids

\begin{tabular}{|c|c|}
\hline & Function 1 \\
\hline Batsmen & 1.545 \\
\hline Pacers & -1.545 \\
\hline
\end{tabular}

Fig. 2. Group Centroids of Discriminant Model

men) has a corrected mean of 1.545 , while group 2 has a revised mean of -1.545 (Pacers). This indicates that the midway between these two is 0 . By placing the midpoint of these two groups' means on a straight line, as illustrated in figure 2, these two groups' means can be plotted on a straight line.

The decision rule for assigning a new subject into either of two groups is depicted in the diagram above. If any new subject's discriminant score falls to the right of the midpoint $(\mathrm{F} 1>0)$, then the subject will be classified into batsmen group, and if it falls to the left of the mid-point $(\mathrm{F} 1<0)$, the subject will be classified into pacers group.

Table 7 shows the classification matrix, which is a description of correct and incorrect subject classification cases in to one of the two groups on the basis of selected parameters 
Table 7. Classification Results (DA)

\begin{tabular}{ccccc}
\hline \multirow{2}{*}{ Observations results } & Variant & \multicolumn{3}{c}{ Classification Results } \\
\cline { 3 - 5 } & & Batsmen & Pacers & Total \\
\hline \multirow{2}{*}{ Count } & Batsmen & 28 & 2 & 30 \\
& Pacers & 2 & 28 & 30 \\
\hline$\%$ & Batsmen & 93.3 & 6.7 & 100.0 \\
& Pacers & 6.7 & 93.3 & 100.0 \\
\hline
\end{tabular}

${ }^{*} 93.3 \%$ of correctly classified original group cases

through which discriminant model has been developed. The above table shows that out of 30 players (batsmen) 28 (93.3\%) players were correctly classified by the discriminant model but other 2 (6.7) players were wrongly classified in another group (pacers). On other hand in case of (pacers) out of 30 players $28(93.3 \%)$ players were correctly classified by the model whereas $2(6.7 \%)$ players were classified wrongly in other group i.e. batsmen. Thus, the model accurately categorized 55 (93.3\%) of the 60 observations, which is a high in percentage, and the model can be regarded accurate \& effective.

\section{Discussion}

The main objective of the study was to develop the model to categorize female cricketers on the basis of physiological and anthropometric parameters for the talent identification purpose. The concept of the present study was to find out the most prominent factors (physiological \& anthropometric) responsible for the classification of cricketers into one of the area of specialty i.e. batsmen, \& pacers as well as the contribution of each variables selected by the model for the discrimination purpose and the study supported by Stretch (1987), Bagchi and Raizada (2020) also concluded that difference exist between batsmen and bowlers in physical, anthropometric and morphological characteristics. However, the another study by Stretch \& Buys (1991) reported contradictory findings in his study with no significant differences in the height, girth, diameters, and skin fold measurement among batsmen, bowlers and all-rounder.

After applying discriminant analysis, the first two predicting variables identified by discriminating model among all the selected variables by the model were Muscle Mass and fat mass. There is no doubt that the excellent performance in any games and sports is highly influenced by body composition (Brechue et al., 2010; Gacesa et. al., 2011; Prado et al., 2006). The body composition consists of fat mass and lean body mass (muscle mass and bone density and fluids). When it comes to fat mass, fat is not a contractile tissue and it also represents extra weight that the athlete must bear when performing a movement, so it appears that in activities that require a body to be pushed through space, calculated body fat percentage has been thought to negatively affect performance. The findings supported by Potteiger et al. (2010) in which he strongly mentioned that the excessive body fat reduced the skating speed of the ice hockey players would lead to minimize the force production. In a cricket match, a cricket players require fastest running between the wicket in a shortest time duration as a batsman, a cricket players require great linear momentum of the body to transfer his or her generated body momentum to the ball in the line of the wicket to get the wicket as well as to secure more run as a pacer also as a fielder they have to chase the ball quickly and react accordingly and to do these task efficiently every cricket players either batsmen, pacer or spinners must keep his or her body fat very low or can say in a optimum require level. On the other hand an increased muscle mass has been confirmed to improve overall performance in all games and sports. There is a positive relation of muscles and the forces generated by these muscles (Högström et al., 2012; Carbuhn et al., 2010). So further to this it may assume that the body with increased muscles mass has capability to generate more force and power, resulting the batsmen may hit the bigger shots (Boundaries) to score more runs, pacers may give the more speed to the ball to get the more wicket as well all the batsmen or bowler as a fielder may give the long and accurate throw from the boundary line to save the score for their teams. So, the ideal muscles mass can be convinced easily to all of us as the best predictor of enhancing performance not only in cricket but also in all games and sports.

The other predicted variable that was identified by the discriminant model was Shoulder Diameter. There is no denying that a broad shoulder implies a high degree of strength of the arm. Regarding shoulder strength, to score the most runs, a batsman needs good shoulder strength to hit the ball out of the boundary. So, as much as the strength in the shoulder with a great timing as a batman, bat speed increases lead the ball covers the maximum horizontal distance resulting sixes and fours. In case of bowlers, for the faster and good length delivery of the ball they need to hold a good strength in the shoulder. Because pace bowlers have broad shoulders, they are typically fielded on the boundary line in many matches and can quickly pass the ball to the wicketkeeper's gloves. The finding supported by sketch reported broad shoulders of bowler compared to batsman as anthropometric characteristic and the study supports in discriminating pace bowlers and batsmen on the basis of shoulder diameter. Many other researchers also argued in their findings as a support that in the modern cricket format like T-20 as well as the IPL where the cricket match becomes so fast and skillful aimed scoring maximum scores in the given balls. So, to survive in this fast format of modern cricket the more focus of the batsmen on power hitting shots to score more through boundaries rather a defensive stroke because the boundaries give player's an opportunity to score more runs in a single ball (Spaniol et al., 2006; Basile et al., 2007; Bonnete et al., 2008).

On the other hand as considering the playing position, Stretch \& Buys (1991) reported contradictory findings in his study with no significant differences in the height, girth, diameters, and skinfold measurement among batsmen, bowlers and all-rounder. 


\section{Conclusion}

The researcher's discriminant model (Batsmen and Pace - Bowler) meets all of the relevant assumptions. The discriminant model explained 71.9 percent of the variation. The discriminant model reveals that the subjects were successfully classified into groups with high accuracy. Overall, 93.2 percent of the cricketers were correctly identified, according to the classification matrices, along with developed disrciminant function $\mathrm{F} 1=-29.531+(1.311 \times$ Muscle mass $)$ $+(-0.182 \times$ Fat $)+(0.292 \times$ Shoulder Diameter $)$. As a result, the model is quite good at classifying subjects into one of two groups. Three predictor variables which are selected by the model were muscle mass, fat, and shoulder diameter.

\section{Conflict of Interest}

Authors declare no conflict of interest.

\section{References}

Ahamad, G., Naqvi, S. K., \& Beg, M. M. S. (2016). An OWABased Model for Talent Enhancement in Cricket. International Journal of Intelligent Systems, 31(8), 763785. https://doi.org/10.1002/int.21802

Peltola, E. (1992). Talent Identification. Sports Psychology Bulletin, 3(5), 10-11.

Williams, A.M. \& Reilly, T. (2000). Talent Identification and Development in Soccer. Journal of Sports Sciences, 18(9), 657-667. https://doi.org/10.1080/02640410050120041

Mallillin, T., Collantes, B.E., GO, M.R., Platoon, S.G., \& Villegas, R.A. (2007). Sports talent identification in 1 st and 2 nd year UST high school students. Philippine journal of allied health sciences, 2(1), 41-42. https://doi.org/10.1016/j.procs.2015.08.426

Noakes, T. D., \& Durandt, J. J. (2000). Physiological requirements of cricket. Journal of Sports Sciences, 18, 919-929. https://doi.org/10.1080/026404100446739

Hoque, N. (2019). Anthropometric Characteristics and Physiological Fitness Status of Male Cricket Players of Kerala. Journal of Emerging Technologies and Innovative Research, 6(1), 712-718

Johnstone, J.A., Mitchell, A.C., Hughes, G., Watson, T., Ford, P.A., \& Garrett, A.T. (2014). The athletic profile of fast bowling in cricket: A review. Journal of Strength and Conditioning Research, 28(5), 1465-1473. https://doi.org/10.1519/JSC.0b013e3182a20f8c

Pyne, D.B., Duthie, G.M., Saunders P.U., Petersen, C.A., \& Portus, M. (2006). Anthropometric and strength correlates of fast bowling speed in junior and senior cricketers. Journal of Strength and Conditioning Research, 20(3), 620-626.

Christie, C.A. (2012). The Physical Demands of Batting and Fast Bowling in Cricket, An International Perspective on Topics in Sports Medicine and Sports Injury, Dr. Kenneth R. Zaslav (Ed.), InTech.

Rudkin, S.T., \& O’Donogue, P.G. (2008). Time motion analysis of first-class cricket fielding. Journal of Science and Medicine in Sport, 11(6), 604-607. https://doi.org/10.1016/j.jsams.2007.08.004

Gore, C.J., Bourdon, P.C., Woolford, S.M., \& Pederson, D.G. (1993). Involuntary dehydration during cricket. International Journal of Sports Medicine, 14(7), 387-395. https://doi.org/10.1055/s-2007-1021197

Leone, M., Lariviere, G., \& Comtois, A.S. (2002). Discriminant analysis of anthropometric and biomotor variables among elite adolescent female athletes in four sports. Journal of sports sciences, 20(6), 443-9. https://doi.org/10.1080/02640410252925116

Koley, S. (2006). New Horizons in Kinanthropometry. New Delhi: Friends Publications.

Landers, G. J., Blanksby, B. A., Ackland, T. R., \& Smith, D. (2000). Morphology and performance of world championship triathletes. Annals of Human Biology, 27(4), 387-400. https://doi.org/10.1080/03014460050044865

Nazeer, M. T., Haq, M. Z. U., \& Habib, M. B. (2018). Anthropometric and Physical Fitness of the Under-16 Regional-School Cricket Players, of Bahawalpur, Pakistan. Global Regional Review, Humanity, 3(1), 333342. https://doi.org/10.31703/grr.2018(III-I).24

Bartlett, R. M. (2003). The science and medicine of cricket: an overview and update. Journal of Sports Sciences, 21(9), 733-752. https://doi.org/10.1080/0264041031000140257

Woolmer, B., Noakes, T., \& Moffett, H. (2008). Bob Woolmer's Art and Science of Cricket (1st ed.). Sydney: New Holland Publishers Ltd.

Stretch, R. A. (1987). Anthropometric profile of first-class cricketers. South African Journal for Research in Sport Physical Education and Recreation, 10(1), 65-75.

Thomas, J.R., Nelson, J.K., \& Silverman, S.J. (2011). Research method in Physical Activity (6th ed.). Human Kinetics, 173-175.

Verma, J.P. (2013). Data Analysis in Management with SPSSSoftware (1st ed.). Dordrecht London: Springer, 389407. https://doi.org/10.1007/978-81-322-0786-3

Tew, J., \& Wood, M. (1980). Proposed Model for Predicting Probable Success in Football Players. Houton, TX: Rice University Press.

Bagchi, A., \& Raizada, S. (2020). Development of the Discriminant Model for Classifying Cricketers Based on Anthropometric and Physical Variables. Annals of Tropical Medicine and Public Health, 23(17). https://doi.org/10.36295/ASRO.2020.231759

Pollock, M.L., Jackson, A.S., \& Pate, R.R. (2013). Discriminant Analysis of Physiological Differences between Good and Elite Distance Runners. Research Quarterly for Exercise and Sport, 51(3), 521-532.

https://doi.org/10.1080/02701367.1980.10608075

Pion, J., Segers, V., Fransen, J., Debuyck, G., Deprez, D., Haerens, L., et. al. (2015). Generic anthropometric and performance characteristics among elite adolescent boys in nine different sports. European Journal of Sport Science, 15 (5), 357-66. https://doi.org/10.1080/17461391.2014.944875

McArdle, W.D., Katch, F., Pechar, G., Jacobson, L., \& Ruck, S. (1972). Reliability and interrelationships between maximal oxygen intake, physical work capacity and steptest scores in college women. Medicine and science in sports, 4(4), 182-186. https://doi.org/10.1249/00005768-197200440-00019

Stretch, R.A., \& Buys, F.J. (1991). Anthropometric profile and body composition changes in first-class cricketers. South African Journal for Research in Sport, Physical Education and Recreation, 14(2), 57-64.

Brechue, W., Mayhew, J., \& Piper, F.C. (2010). Characteristics of Sprint Performance in College football Players. Journal strength and conditioning, 24(5), 1169-78. https://doi.org/10.1519/JSC.0b013e3181d68107

Gacesa, J. P., Borak, O., Jakovljevic, D.K., Klasnja, A., Galic, V., Drapsin, M. et. al. (2011). Body mass index and body fat content in elite athletes. Exercise and Quality of Life, 3(2), 43-48. 
Prado, W.L.D., Botero, J.P., Guerra, R.L.F., Rodrigues, C.L., Cuvello, L.C.F., \& Dâmaso, A.R. (2006). Anthropometric profile and macronutrient intake in professional Brazilian soccer players according to their field positioning. Rev Bras Med Esporte, 2(12), 61-65.

https://doi.org/10.1590/S1517-86922006000200001

Potteiger, J. A, Smith, D. L, Maier, M. L, \& Foster, T. S. (2010). Relationship Between Body Composition, Leg Strength, Anaerobic Power, and On-Ice Skating Performance in Division I Men's Hockey Athletes. Journal of Strength and Conditioning Research, 24(7), 1755-1762.

https://doi.org/10.1519/JSC.0b013e3181e06cfb

Högström, G. M., Pietilä, T., Nordström, P., \& Nordström, A. (2012). Body Composition and Performance. Journal of Strength and Conditioning Research, 26(7), 1799-1804. https://doi.org/10.1519/JSC.0b013e318237e8da

Carbuhn, A.F., Fernandez, T.E., Bragg, A.F., Green, J.S., \& Crouse, S.F. (2010). Sport and training influence bone and body composition in women collegiate athletes. Journal Strength Conditioning, 24(7), 1710-1717. https://doi.org/10.1519/JSC.0b013e3181d09eb3

Spaniol, F.J., Bonnette, R., Melrose, D., \& Bohling, M. (2006). Physiological predictors of bat speed and batted-ball velocity in NCAA Division I baseball players. Journal of Strength Conditioning, 20(4), 20-25. https://doi.org/10.1519/JSC.0b013e3181f0a76a

Basile, R., Otto, R., \& Wygand, J. (2007). The relationship between physical and physiological performance measures and baseball performance measures. Medicine Science Sports Exercise, 39(5), 14-21.

https://doi.org/10.1249/01.mss.0000273807.89364.04

Bonnette, R., Spaniol, F., Melrose, D., Ocker, L., Paluseo, J., \& Szymanski, D. (2008). The relationship between rotational power, bat speed, and batted-ball velocity of NCAA Division I baseball players. Journal of Strength Conditioning, 22, 112-122.

\title{
ДИСКРИМІНАНТНА МОДЕЛЬ ДЛЯ ОРІЕНТОВАНОГО НА НАВИЧКИ ПРОГНОЗУВАННЯ У ЖІНОК-ГРАВЦІВ У КРИКЕТ НА ОСНОВІ ВИБРАНИХ ПАРАМЕТРІВ РЕЗУЛЬТАТИВНОСТІ
}

\author{
Сапна Мандолі ${ }^{1 \mathrm{ABCD}}$, Діпак Шарма ${ }^{1 \mathrm{ABD}}$, Хем Чандра Джоші ${ }^{1 \mathrm{ABCD}}$ \\ ${ }^{1}$ Національний інститут фізичного виховання імені Лакшмі Бай \\ Авторський вклад: А - дизайн дослідження; В - збір даних; C - статаналіз; D - підготовка рукопису; Е - збір коштів \\ Реферат. Стаття: 7 с., 7 табл., 2 рис., 35 джерел.
}

Мета дослідження - розробити дискримінантну модель для гравців у крикет на основі фізіологічних та антропометричних змінних.

Матеріали та методи. У дослідженні взяли участь шістдесят жінок-гравців старшого віку Управління 3 контролю за крикетом в Індії, представниць п'яти різних штатів, середній вік яких становив 23,4 $\pm 2,03$, середній зріст 152,1 $\pm 3,44$ та середня вага 52,4 $\pm 4,21$. Для прогнозування результативності у крикеті використовувався багатовимірний метод 3 класифікацією гравців на бетсменів і пейс-боулерів на основі вибраних фізіологічних та антропометричних змінних.

Результати. Усі припущення були повністю виконані (тест Шапіро-Уілка $\mathrm{p}>0,05$ та $\mathrm{F}=8,121, \mathrm{p}=0,264$ за М-тестом Бокса) для застосування дискримінантного аналізу та розробки моделі. Спочатку для дослідження було відібрано одинадцять змінних результативності, а після застосування поетапного статистичного методу дискримінантного аналізу модель вибрала певні змінні, а саме: м'язова маса $(1,311)$, жир $(-0,182)$ та діаметр плеча $(0,292)$, модель показала свою ефективність, оскільки власне значення відповідної моделі становило 0,848 .

Висновок. Розроблено дискримінантну функцію $\mathrm{F} 1=-29,531+(1,311 \times$ м'язова маса $)+(-0,182 \times$ жир $)+$ $(0,292 \times$ діаметр плеча). Відсоток загальної варіації, що пояснюється моделлю, становив 71,9\%. Загалом 93,2\% спостережень було правильно класифіковано за допомогою запропонованої дискримінантної моделі.

Ключові слова: дискримінантна модель, лямбда Уілкса, власне значення, класифікаційна матриця.

\section{Information about the authors:}

Mandoli Sapna: mandolisapna824@gmail.com; https://orcid.org/0000-0001-9475-9816; Lakshmibai National Institute of Physical Education, Department of Exercise Physiology, Shaktinagar, Mela Road, Gwalior, Madhya Pradesh, Pin Code-474002, India.

Sharma Deepak: deepaklnupe@rediffmail.com; https://orcid.org/0000-0003-3683-5184; Lakshmibai National Institute of Physical Education, Department of Exercise Physiology, Shaktinagar, Mela Road, Gwalior, Madhya Pradesh, Pin Code-474002, India. Joshi Hem Chandra: hemjoshi380@gmail.com; https://orcid.org/0000-0002-3589-2788; Lakshmibai National Institute of Physical Education, NERC, Department of Sports Biomechanics, Guwahati, Assam, Pin Code-782402, India.

Cite this article as: Mandoli, S., Sharma, D., \& Joshi, H. C. (2021). A Discriminant Model for Skill Oriented Prediction of Female Cricketers Depend Upon Selected Performance Parameters. Teorîa ta Metodika Fizičnogo Vihovannâ, 21(4), $293-298$. https://doi.org/10.17309/tmfv.2021.4.01

Received: 12.09.2021. Accepted: 16.10.2021. Published: 25.12.2021

This work is licensed under a Creative Commons Attribution 4.0 International License (http://creativecommons.org/licenses/by/4.0). 